\title{
Cikkismertetés: Légszennyezés és a gyermekek légúti megbetegedései Londonban
}

\author{
Article review: Air pollution and children's respiratory health in London
}

Ismertető: $\quad$ Márovics Gergely $\square$

Pécsi Tudományegyetem, Általános Orvosi Kar, Orvosi Népegészségtani Intézet

Ismertetett cikk: Mudway IS, Dundas I, Wood HE et al. Impact of London's low emission zone on air quality and children's respiratory health: a sequential annual cross-sectional study The Lancet Public Health Vol. 4. 2018. november 14. doi: 10.1016/S2468-2667(18)30202-0

Beküldve: $\quad$ 2019. 02. 27.

doi: $\quad$ 10.24365/ef.v60i2.428

Kulcsszavak: levegőminőség; légszennyezés; légúti megbetegedés; asztma

Keywords: air quality; air pollution; respiratory disease; asthma

\section{BEVEZETÉS}

Ez a brit tanulmány azt vizsgálta, hogy van-e összefüggés a nitrogén-oxidok, a 2,5 $\mu$ m-nél $\left(P_{2,5}\right)$ és a $10 \mu \mathrm{m}$-nél $\left(\mathrm{PM}_{10}\right)$ kisebb átmérőjű részecskékből álló anyagok, továbbá a tüdőfunkció, valamint a légúti és allergiás tünetek között. $A P_{2,5}$ főleg égésből származó részecskéket takar, amik képesek lerakódni a légutakban és a tüdőben; jelentős mennyiségú egészségkárosító komponenst tartalmaznak. A PM 10 frakció főként ásványi részecskékből áll, fő forrása városi környezetben a közlekedés által felkavart, ipari tevékenységből vagy építési munkákból származó por; tömegéhez képest kevesebb egészségkárosító anyagot tartalmaz, de a tüdőben lerakódása jelentős lehet. A tanulmány azért fontos, mert a légszennyezés miatt bekövetkező elhalálozás napjainkra a vezető halálokok közé tornázta fel magát. Az Egészségügyi Világszervezet (World Health Organization, WHO) becslése szerint közel 7 millió ember korai halálát légszennyezés okozta 2012-ben. Egyes tanulmányok rámutattak, hogy a légszennyezés káros hatásai kapcsolatba hozhatók többek között a koraszüléssel, a gyermekkori asztma kialakulásával, valamint a szív- és tüdőbetegségek okozta korai halálozással is. A kutatás célja a gyermekkori légzőszervi betegségek és légszennyezés kapcsolatának vizsgálata volt, továbbá annak összehasonlítása, hogy az alacsony légszennyezettségű területeken mért eredmények különböznek-e a korábbi, rossz levegőminőségű területeken végzett vizsgálatok adataitól.

\section{MÓDSZER}

A vizsgálatba 28 olyan londoni általános iskolát vontak be, melyek közelében levegőminőségmérőállomás múködik. Ezen iskolák minden 4. osztályos diákja (8-9 évesek) részt vett a vizsgálatban (202fő az előzetes vizsgálatban, 2164 fő az 5 éves felmérésben). Az adatgyújtést mindig télen végezték: az előzetes felmérés 2008. november és 2009. január között valósult meg, a tulajdonképpeni vizsgálat pedig 2009-2014 között, novembertôl márciusig vagy áprilisig tartott. A vizsgálat ideje alatt 
minden évben felmérték a diákok egészségi állapotát, tüdőfunkcióját, valamint a kutatók biológiai mintákat gyűjtöttek. A vizsgálatban részt vevő diákok nemre, korra, etnikai hovatartozására és lakcímére vonatkozó adatait az iskolák nyilvántartásából nyerték. A tanulók társadalmi-gazdasági helyzetét az összetett deprivációs index (Index of Multiple Deprivation, IMD) segítségével határozták meg. Ahhoz, hogy a vizsgálat során megbecsüljék a diákok légszennyezettségnek való kitettségét, a nitrogén-oxidok, a $P M_{2,5}$ és a $P M_{10}$ átmérőjú részecskékből álló anyagok térképeit és óránkénti meteorológiai adatokat használtak fel a tanulmányban, az értékeket pedig súlyozták az otthon és az iskolában eltöltött idő arányával (0,884, illetve 0,156). Az egyes szennyezőanyagok átlagos koncentrációját minden esetben közvetlenül a tüdőfunkció-vizsgálat előtt számították ki. Ahhoz, hogy a légszennyezés okozta rövid és hosszú távú hatásokat külön vizsgálhassák, 3 órás (6:00-9:00, iskolakezdés előtti), 24 órás és 7 napos kategóriákra bontották a szennyezőanyagok koncentrációjának mérését. A tüdőfunkció-vizsgálathoz hörgőtágító gyógyszer beadása utáni erőltetett kilégzési másodperctérfogatot $\left(F E V_{1}\right)$ és erőltetett kilégzési vitálkapacitást (FVC) mértek. A kapott eredményeket statisztikai vizsgálatnak vetették alá.

\section{EREDMÉNYEK}

2009-ben a vizsgálatban részt vevő gyerekek 99\%-a élt olyan területen, ahol a nitrogén-dioxid értéke meghaladta az Európai Unió által meghatározott $40 \mathrm{\mu g} / \mathrm{m}^{3}$ éves határértéket, 2013-ra viszont ez az arány 34\%-ra csökkent. Ez idő alatt nitrogén-dioxid csökkenést tapasztaltak mind az utak mentén (medián=-1,35 $\mu \mathrm{g} / \mathrm{m}^{3}$ per év; 95\%-os hitelesség mellett $-2,09--0,61 ; p=0,0004)$, mind pedig az úgynevezett háttérterületeken (medián $=-0,97 \mu \mathrm{g} / \mathrm{m}^{3}$ per év; 95\%-os hitelesség mellett -1,56 - -0,38; $\mathrm{p}=0,0013)$, de a $\mathrm{PM}_{10}$-koncentráció nem csökkent. A PM 2,5 értékek változása nem volt egyértelmú a vizsgálat ideje alatt. Nem találtak összefüggést a hörgőtágító gyógyszer beadása utáni $F E V_{1}$ értékek és a lakónegyedek éves légszennyezettségi értékei között. Az FVC eredmények fordítottan arányosak az éves nitrogén-dioxid értékekkel (medián $=-0,0023$ l/ug per $\mathrm{m}^{3} ; 95 \%$-os hitelesség mellett -0,0044 - 0,$0002 ; p=0,033$ ) és a $P M_{10}$ értékekkel (medián=$0,009 \mathrm{l} / \mu \mathrm{g}$ per $\mathrm{m}^{3} ; 95 \%$-os hitelesség mellett-0,0175 $--0,0005 ; p=0,038)$.

\section{TANULSÁGOK A HAZAI SZAKEMBEREK SZÁMÁRA}

Habár Londonban nem tudtak összefüggést kimutatni a hörgőtágító gyógyszer beadása utáni FEV1 értékek és a légszennyezettség mértéke között, valamint az FVC és a nitrogén-dioxid értékek fordítottan arányosak voltak, az ilyen vizsgálatok mégsem haszontalanok. Hazánkban is számos tanulmány született a levegőminőség és a légzőszervi betegségek kapcsolatáról. A kialakított módszertant felhasználva, friss adatok segítségével tovább lehetne tanulmányozni az összefüggéseket. 